\title{
THE IMPACT OF THE COVID-19 PANDEMIC ON THE UNEMPLOYMENT RATE IN LATVIA
}

\author{
*Vera Hohlova, Baiba Rivža \\ Latvia University of Life Sciences and Technologies, Latvia \\ *Corresponding author's email: veragaidai@gmail.com
}

\begin{abstract}
The economic and labour market consequences of Covid-19 were immediate, significant and lasting, with longterm negative effects on global economic development and activity in general. The global virus pandemic is having a profound effect on the labour market with a sharp rise in the number of unemployed, which are at high risk of becoming long-term unemployed as the pandemic drags on, some of whom will not return to the labour market. The outbreak of Covid-19 and the measures taken to combat it are leading to a rapid demand for unemployment benefits, but a large proportion of the unemployed registered with employment agencies are not actively involved in job search or do not want to establish an employment relationship at all. It is important to track and describe the major changes in the labour market around the world, but the restrictions that are being put in place to combat Covid-19 pose a huge obstacle to conventional data collection approaches and activities. Within the framework of this study, the unemployed in Latvia were interviewed in order to find out and evaluate the impact of the Covid-19 pandemic on the unemployment rate and the unemployed in Latvia. The aim of the article is to find out problems caused by the Covid-19 pandemic, which are related to the unemployed and which need to be solved in Latvia, and possibly also in other European and other countries of the world.
\end{abstract}

Key words: unemployed, unemployment rate, Covid-19, unemployment, unemployed women, long-term unemployment.

\section{Introduction}

The International Labour Organization (ILO) has issued a statement that the world of work is deeply affected by the global virus pandemic. It is not just the health of society as a whole that is at stake: economic and social conditions threaten the long-term livelihoods and well-being of millions. Both the ILO and national governments, workers and employers will have a crucial role to play in tackling the flammable crisis by ensuring the sustainability of businesses and jobs (ILO, 2021).

The ILO standard definition of unemployment reveals that unemployed are persons who are without work / a job and who have been actively looking for work in the last four weeks and are available to start work in the next two weeks. The outbreak of Covid-19 and the measures taken to combat it have led to a sharp increase in the demand for unemployment benefits throughout the European Union (ES). However, a large proportion of the unemployed who have registered with employment agencies are not actively involved in job search or are no longer available for employment, such as those who have to take care of a child who does not attend pre-school or school. This circumstance has led to a mismatch between the number of registered unemployed and the number considered unemployed according to the ILO definition (Eurostat Statistics Explained, 2021).

The economic and labour market consequences of Covid-19 were immediate, very significant now and are likely to be felt in the future. These consequences affect many millions of workers in many countries; some workers can continue working remotely, but there are also a significant number of people who acknowledge that their standard of living has either fallen or that they have no income at all. Workers in the field of health or public safety are undergoing other changes, namely a significant increase in the workload in times of crisis. Official statistics from around the world are currently aimed at tracking and describing all these changes. The restrictions imposed to combat Covid-19 pose a huge obstacle to conventional data collection approaches and activities, and it is taking place at a time when there is a massive increase in the demand for information. The ILO has approached national statistical offices to find out the impact of Covid-19 on statistical activities in the field of labour statistics, mainly to find out the activities of the National Labour Force Survey. The aim is to share the information gathered so that countries can learn from other countries' experiences. The biggest challenge facing all countries is to maintain continuity and quality, while responding to changing circumstances and being flexible (ISOLAT, 2020).

\section{Materials and Methods \\ Participants and Recruitment}

In order to find out the impact of the Covid-19 pandemic on the unemployment rate in Latvia, a study was conducted, during which Latvian unemployed people were interviewed.

The survey was conducted by the research centre SKDS, which has been a member of E.S.O.M.A.R. (European Society for Opinion and Market Research) and operates in accordance with all the ethical and methodological rules and standards, set by that organization for public opinion and market research institutes. Since 2014, the research centre SKDS has 
been represented in the WIN network of research companies (SDS, 2020).

The survey was completed by 216 unemployed people aged 18 and over. Data were collected in the time period from October 29, 2020 to November 2, 2020.

Starting from October 2020, the number of people infected with Covid-19 in Latvia increased significantly. If from 31 August 2020 to 6 September 2020 the number of infected persons increased by 1428 , then at the beginning of October from 5 October 2020 to 11 October 2020 the number of infected persons was 2670, while from 20202 By November 8,2020 , the number of infected had already reached 8095 (COVID-19, 2021).

On November 6, 2020, the Cabinet of Ministers of the Republic of Latvia (RL) declared a state of emergency from November 9, 2020 to April 6, 2021. All on-site public events as well as private events and private gatherings were cancelled and prohibited, except for events within one household. Only those sports trainings (classes) that could take place outdoors were allowed - swimming pools, gyms, children's sports classes in the premises were closed, catering facilities were only allowed for takeout. Cultural venues and exhibition venues had been suspended. Beauty services were not provided, only grocery stores, pet shops, pharmacies were allowed to operate; however, the range of goods that could be sold was strictly regulated. Employers were obliged to provide employees with opportunities for remote work if the specifics of the work allowed it, as well as to organize work so that only those employees who ensured the continuity of work and could not do it remotely at their place of residence (LR Cabinet of Ministers, 2020).

Survey Development

Existing research and data on the unemployed were reviewed and informal talks with the unemployed provided information on problems and possible solutions. At the beginning of the survey, demographic information was clarified and only those respondents who were unemployed were selected with filter questions. It was initially determined whether the respondent had the status of a registered unemployed person or whether he / she was an unregistered unemployed person. This question was chosen because the State Employment Agency of the Republic of Latvia, similarly to the employment agencies of other countries, provides statistical data only on registered unemployment in the country. This article will report both the data obtained from the survey and the official statistics related to the purpose of the study.

Demographic characteristics included the age, gender, marital status, level of education, income, nationality and region of residence. Specific answers to the questions were offered.

The seven questions in the survey focused on the circumstances of the Covid-19 pandemic. It was asked whether the Covid-19 pandemic was a reason for termination of employment, whether claiming registered unemployment was an employer's recommendation to receive unemployment benefits, whether the person planned to return to work with a previous employer, whether the Covid-19 pandemic has affected wage claims or has influenced attitudes towards employment.

\section{Results and Disscusion}

In its January 2021 report, the World Bank predicts that, like previous economic crises, the Covid-19 pandemic will have lasting negative effects on global economic development and activity, as well as per capita income. The World Bank emphasizes the particular importance of institutional reforms to foster growth in the face of weak fiscal positions and rising debt. Only a comprehensive policy effort can restore stable, sustainable and equitable growth (World Bank, 2021).

EU countries are bound by Regulation (EC) No 1466/97 "Strengthening the surveillance of budgetary positions and the surveillance and coordination of economic policies". The purpose of this regulation is to prevent and coordinate the budgetary policies of the EU countries in order to ensure budgetary discipline within the EU. EU countries must submit stability programs to the European Commission, setting out medium-term budgetary objectives. The Commission evaluates the programs and the Council of Europe makes country-specific recommendations (EUR-lex, 2017).

According to the Latvian Stability Program for 2020-2023 with the global crisis caused by Covid-19 and the sharp decline in economic activity in Latvia in March and April 2020, the unemployment rate has started to rise sharply, in one and half months time or by April 17 with the number of registered unemployed increasing by 10,616 or $18.2 \%$ and the registered unemployment rate rising to $7.4 \%$. According to the data of the Ministry of Welfare, by 17 April 2020, notices of collective redundancies had been submitted by 28 companies for a total of 4,118 employees. In turn, 15,064 employees have received downtime benefits since April 6. The number of vacancies, which rose sharply in 2019, fell sharply in March and April 2020, with the number of job advertisements on the recruitment company's CV Online portal declining by around $50 \%$ within one month by 17 April 2020 .

The Covid-19 impact scenario assumes that due to the spread of the virus and measures to control it, the number of people employed in the economy will 
decrease by an average of 45 thousand or $5 \%$ in 2020 , losing part of the workforce in the directly affected sectors, including transport, trade, accommodation and catering, professional and administrative services. Accordingly, the unemployment rate in 2020 was expected to increase by 4.9 percentage points to $11.2 \%$ compared to 2019. In 2021 and 2022, as economic growth resumes, the number of employees will increase slightly, stabilizing at 883 thousand by 2023 (LR Ministry of Finance, 2020).

At present, it is not clear whether the optimistic forecasts of the Ministry of Finance of the Republic of Latvia on the resumption of economic growth in 2021, recorded in the Latvian Stability Program, will come true, as the emergency situation in Latvia has been extended until April 6, 2021 (LR Ministry of Health, 2021), and on February 24, 2021, the Minister of Health of the Republic of Latvia reports that if the rapid spread of a new strain of the virus, which was discovered in Great Britain and has already entered Latvia, occurs in Latvia, the government will decide to introduce even stricter security measures (Latvian Public Media, 2021).

The Latvian Stability Program of the Ministry of Finance also stated that the Covid-19 impact scenario has been developed under very high uncertainty and the risks of the scenario are downward (LR Ministry of Finance, 2020) and the increase in the unemployment rate set in the program to $11.2 \%$ in 2020 was not achieved (in December 2020 the actual unemployment rate was $8.2 \%$ ), and such a percentage indicator was not achieved also in the beginning of 2021 (in January 2021 the actual unemployment rate was 8.8\%) (Central Statistical Bureau, 2021); however, there is a tendency for unemployment to continue to rise.

216 unemployed Latvians in the age group of 18 to 63 participated in the survey of this study. The largest number of respondents is in the age group from 55 to 63 years $(27.8 \%)$, followed by the group of respondents from 35 to 44 years $(25.9 \%)$, while the lowest number of surveyed unemployed is in the age group from 18 to 24 years $(7.9 \%)$.

$72.7 \%$ of women and $27.3 \%$ of men, respectively, participated in the survey. $49.1 \%$ of respondents have acquired secondary or secondary special education, a very similar number of respondents (43.1\%) have higher education, while the unemployed with basic education this time are $7.9 \%$. The majority of respondents identify themselves as Latvian (76.9\%), $16.7 \%$ - Russians, 2.8\% - Belarusians, 0.9\% Ukrainians and the same number of Poles, $0.5 \%$ Lithuanians and $1.4 \%$ chose the answer "other". $93.1 \%$ of respondents are Latvian citizens and $6.9 \%$ of respondents do not have Latvian citizenship. $61.6 \%$ of the unemployed indicated that they were unemployed as their main occupation, $11.6 \%$ indicated that they were students, while $26.9 \%$ identified themselves as a housewife / househusband.

The World Bank points out that a package of reforms aimed at investing in human capital, physical capital and increasing women's participation in the labour force could help address the expected negative effects of the pandemic and boost potential growth over the next decade (World Bank, 2021).

The results of the study indicate that the majority of respondents to the survey are women (72.7\%).

According to the SEA data of the Republic of Latvia, at the end of December 2020, 54.9\% $(38,185)$ of the total number of registered unemployed $(69,605)$ were women and $45.1 \%(31,420)$ were men (NEA, 2020). Although the difference in the number of registered unemployed by gender is not as cardinal as found in the study, it is important to clarify that the NEA offers statistics only on the registered unemployed, while the study also included unregistered unemployed, some of whom did not intend to cooperate or do not cooperate with NEA. Given the fact that the study found that a relatively large number of unemployed do not plan to enter employment, it is important to pay attention not only to long-term unemployment, but also in line with the World Bank's findings, it is necessary

Distribution of respondents by age groups

Table 1

\begin{tabular}{|c|c|c|c|c|c|}
\hline \multicolumn{2}{|c|}{ Age } \\
\hline \multirow{3}{*}{} & Frequency & Percent & Valid Percent & Cumulative Percent \\
\hline \multirow{3}{*}{ Valid } & $18-24$ & 17 & 7.9 & 7.9 & 7.9 \\
\cline { 2 - 6 } & $25-34$ & 34 & 15.7 & 15.7 & 23.6 \\
\cline { 2 - 6 } & $35-44$ & 56 & 25.9 & 25.9 & 49.5 \\
\cline { 2 - 6 } & $45-54$ & 49 & 22.7 & 22.7 & 72.2 \\
\cline { 2 - 6 } & $55-63$ & 60 & 27.8 & 27.8 & 100.0 \\
\cline { 2 - 6 } & Total & 216 & 100.0 & 100.0 & \\
\hline
\end{tabular}


to pay more attention to women's participation in the labour market.

The job losses caused by the Covid-19 crisis are affecting women the most. Women are represented in the sectors most affected, such as leisure and hospitality, healthcare and education, and in many of these areas women are losing their jobs at a disproportionate rate. Labour experts are rightly concerned that, even after the resumption of work and the end of the state of emergency in the countries, many workers, especially in the leisure and hospitality sector, will continue to suffer losses of working hours and income. Economists acknowledge that low-paid workers are the least hired, with a disproportionate number of women (Washington Post).

The ILO points out that, from an economic point of view, reducing the gender gap in labour force participation could significantly increase global GDP. Growth would be huge in the countries with the largest gender gaps, but in many developed countries, annual GDP growth would also increase, which is important in times of almost zero growth.

ILO in partnership with Gallup, Inc. (American analytics and consulting firm) found that $70 \%$ of women, regardless of their employment status, prefer to have a paid job (ILO, 2018).

Of the unemployed who took part in the survey, $81 \%$ said that the Covid-19 pandemic was not a reason for termination of employment, $8.3 \%$ said that the Covid-19 pandemic was a reason for termination of employment, and $10.6 \%$ said that that the Covid-19 pandemic was partly the reason for the termination of employment.

Respondents who acknowledged that Covid-19 was or was in part a reason for termination of employment also answered the question of whether to apply for registered unemployment status and receive unemployment benefits was recommended by the employer. $0.9 \%$ admitted that they received such an employer's recommendation, $6.5 \%$ indicated that obtaining the status of registered unemployed was not an employer's recommendation, while $1.9 \%$ indicated that it is difficult to say whether such an employer's recommendation was received.

Respondents who acknowledged that the Covid-19 pandemic played a role in making them unemployed also answered the question of whether they plan to return to work with their previous employer if they receive such an offer. $39 \%$ admitted that they plan to return to the previous employer and $61 \%$ indicated that they do not.

The situation where the unemployed apply for the status of registered unemployed in order to receive unemployment benefits, but do not plan to look for a job because they will return to work as soon as the previous employer can resume full-fledged economic activity can be explained by the fact that, although the Cabinet of Ministers of the Republic of Latvia issued Regulations on employers affected by the Covid-19 crisis, which qualify for downtime benefit and distribution of overdue tax payments for periods or deferral for up to three years (Cabinet Regulations, 2020), and the purpose of these rules was to compensate for the loss of income in the Covid-19 crisis by providing a downtime allowance for workers and the self-employed, the criteria set out in the rules proved to be too strict. Already by May 2020, amendments were made twice to the relevant regulations of the Cabinet of Ministers and the criteria for receiving the downtime benefit were relaxed. Companies could start applying for downtime allowance from March 25, 2020, and by May 12, 3944 companies received denials of downtime allowance (8249 companies were granted downtime allowance) and in 1816 cases the benefit was refused to the self-employed, who could start applying for the downtime benefit from 3 April to 12 April (granted to 2856 self-employed) (LV portal, 2020).

It should be noted that although the Regulations of the Cabinet of Ministers of the Republic of Latvia on employers affected by the Covid-19 crisis, who qualify for downtime benefit and distribution of overdue tax payments for periods or deferral for up to three years, were amended several times, on January 1, 2021 they lost their validity and were replaced by the Regulations on Support for Downtime of Taxpayers for the Continuation of Their Operations in the Conditions Caused by Covid-19, which entered into force on 28 November 2020 (Regulations of the Cabinet of Ministers, 2020).

In response to the questionnaire, respondents expressed their views on whether the Covid-19 pandemic had affected their wage demands. All 216 respondents answered this question, and the majority of respondents $(39.4 \%)$ answered that they plan to find a job with equal pay, $14.8 \%$ of respondents stated that they are ready to work for lower pay, $15.7 \%$ of respondents are aiming to find a job with a higher wage, while $30.1 \%$ of the unemployed answered that they do not plan to enter into employment at all; therefore, there is a good reason to believe that these unemployed will become long-term unemployed. For a more detailed analysis of this issue, I performed a cross-tabulation analysis comparing the positions of men and women. The Covid-19 pandemic has affected $33.9 \%$ of men, $13.6 \%$ of whom want to find a better paid job, while $20.3 \%$ will agree to work in a lower paid job than before the Covid-19 pandemic. The Covid-19 pandemic has also changed the position of $29.3 \%$ of women surveyed against pay: $16.6 \%$ are aiming to find a better paid job, while $12.7 \%$ of women, on the 


\section{Distribution of women's and men's answers to the question "Has the Covid-19 pandemic affected your pay claims?"}

\begin{tabular}{|c|c|c|c|c|c|c|c|}
\hline \multirow{2}{*}{\multicolumn{3}{|c|}{$\begin{array}{l}\text { Yes, I plan to find a better paid job } \\
\text { Yes, I am also willing to receive a lower salary }\end{array}$}} & \multicolumn{4}{|c|}{ Has the Covid-19 pandemic affected your pay claims? } & \multirow{3}{*}{$\begin{array}{c}\text { Total } \\
100.0 \% \\
\end{array}$} \\
\hline & & & \multirow{2}{*}{$\begin{array}{c}\text { No, I plan } \\
\text { to find a job } \\
\text { with equal } \\
\text { pay }\end{array}$} & \multirow{2}{*}{$\begin{array}{c}\begin{array}{c}\text { I do not plan } \\
\text { to enter an } \\
\text { employment } \\
\text { relationship }\end{array} \\
20.3 \% \\
\end{array}$} & \multirow[b]{2}{*}{$42.4 \%$} & \multirow[b]{2}{*}{$23.7 \%$} & \\
\hline \multirow[t]{6}{*}{ Your gender } & \multirow[t]{3}{*}{ Male } & $\%$ within Your Gender & & & & & \\
\hline & & $\begin{array}{l}\% \text { within Has the } \\
\text { Covid-19 pandemic } \\
\text { affected your pay } \\
\text { claims? }\end{array}$ & $23.5 \%$ & $37.5 \%$ & $29.4 \%$ & $21.5 \%$ & $27.3 \%$ \\
\hline & & $\%$ of Total & $3.7 \%$ & $5.6 \%$ & $11.6 \%$ & $6.5 \%$ & $27.3 \%$ \\
\hline & \multirow[t]{3}{*}{ Female } & $\%$ within Your gender & $16.6 \%$ & $12.7 \%$ & $38.2 \%$ & $32.5 \%$ & $100.0 \%$ \\
\hline & & $\begin{array}{l}\% \text { within Has the } \\
\text { Covid-19 pandemic } \\
\text { affected your pay } \\
\text { claims? }\end{array}$ & $76.5 \%$ & $62.5 \%$ & $70.6 \%$ & $78.5 \%$ & $72.7 \%$ \\
\hline & & $\%$ of Total & $12.0 \%$ & $9.3 \%$ & $27.8 \%$ & $23.6 \%$ & $72.7 \%$ \\
\hline \multirow{3}{*}{\multicolumn{2}{|c|}{$\begin{array}{c}\text { Total } \\
\% \text { within Has the } \\
\text { Covid-19 pandemic } \\
\text { affected your pay claims? } \\
\% \text { of Total }\end{array}$}} & $\%$ within Your gender & $15.7 \%$ & $14.8 \%$ & $39.4 \%$ & $30.1 \%$ & $100.0 \%$ \\
\hline & & $100.0 \%$ & $100.0 \%$ & $100.0 \%$ & $100.0 \%$ & $100.0 \%$ & \\
\hline & & $15.7 \%$ & $14.8 \%$ & $39.4 \%$ & $30.1 \%$ & $100.0 \%$ & \\
\hline
\end{tabular}

contrary, will agree to work for a lower wage. $42.4 \%$ of men and $38.2 \%$ of women nevertheless want to find a job with equal pay. On the other hand, $23.7 \%$ of men and $32.5 \%$ of women do not plan to enter employment at all.

$18.5 \%$ of the unemployed, who admitted to being affected by the Covid-19 pandemic, indicated that they would like to work in a paid state in the future, $6.6 \%$ indicated that they wanted to work in a private sector company, but $74.8 \%$ of the unemployed indicated that The Covid-19 pandemic has not affected their position towards a future employer, and it does not matter whether it will be a public or a private sector employer.

The next two questions focused on whether the unemployed who participated in the survey plan to cooperate with the National Employment Agency (NEA). In accordance with the Law on Unemployment and Support Seekers of the Republic of Latvia, the NEA implements the state policy in the field of reducing unemployment and supporting the unemployed, as well as job seekers and persons at risk of unemployment. The NEA not only registers and counts the unemployed and jobseekers, but also organizes a dialogue between the unemployed and employers to reduce unemployment, as well as organizes or implements active employment measures and preventive unemployment reduction measures (LR Unemployed and Jobseeker Support Law, 2002).

When asked whether the unemployed plan to cooperate with the NEA in order to find a job, 20.4\% answered that they plan to actively cooperate with the NEA, $13.4 \%$ indicated that they are forced to cooperate in order to maintain their registered unemployment status and receive unemployment benefits, 43, $1 \%$ of the unemployed indicated that they do not plan to cooperate with the National Employment Agency with the aim of finding a job, because they plan to find a job on their own or with the help of friends and relatives, and $23.1 \%$ indicated that they do not plan to cooperate with the NEA.

As indicated above, the NEA not only registers and counts the registered unemployed, but also, in cooperation with other state and local government institutions, as well as natural and legal persons, organizes and implements active employment measures and preventive unemployment reduction measures (Cabinet Regulations, 2011). The NEA organizes the following employment or preventive measures: vocational training, retraining or upgrading of qualifications, acquisition of non-formal education, training with an employer, development of skills necessary for work, measures to increase competitiveness, measures for certain groups of persons, paid temporary public work (community 
service), support measures for people with addiction problems, student summer employment events, career counselling. The most used measures are career counselling, which was implemented 52,308 times in 2020; however, the acquisition of non-formal education (10,982 times in 2020) and paid temporary public work $(8,994$ times in 2020) are also quite actively used (NEA, 2020).

The unemployed participants in the study, who admitted that they had decided to cooperate with the NEA, also answered the question whether they had also applied for an active employment measure. 74.7\% of these unemployed answered that they did not use such an opportunity and did not apply, while $25.3 \%$ of the unemployed applied for active employment measures. The unemployed people who applied for active employment measures offered by the NEA were asked to indicate which of the NEA's offers they had decided to use. 16 respondents indicated that they have applied for the courses offered by the NEA; one respondent indicated that they have applied for a professional development education program, two respondents have applied for community service, one respondent has applied for a motivation program, two respondents have applied for career counselling and one respondent stated that "hard to say" what event he has applied for.

The study identified $30.1 \%$ of the unemployed who admitted that they did not plan to enter into an employment relationship at all. These respondents can reasonably be considered as existing long-term unemployed or as unemployed who will become longterm unemployed in the future.

The World Bank predicts that, after more than twenty years of reducing global poverty, the current crisis will restore poverty to its last level in 2017 . The growth of human capital is reduced by long periods of unemployment. Covid-19 could also hinder the development of human capital. Longer periods of unemployment can both discourage workers from remaining in the workforce and discourage the unemployed from entering employment, which also has a negative impact on the skills of workers and the unemployed. Past economic crises have shown that reduction of skills development widens income disparities (World Bank, 2021).

Long-term unemployment (when a person is unemployed for more than 12 months) can have serious negative consequences for the individual, society and its economic system. People who are out of work for a long time find it harder to find work over time. Some also face lower earnings and limited career prospects. Workers' human capital (actual or perceived by the employer) may deteriorate or become obsolete during long-term unemployment.
In addition, the time and willpower spent looking for work tends to decrease. Both elements suggest that the probability of leaving unemployment decreases significantly with the duration of unemployment, which in turn increases the probability of staying unemployed. Over time, as unemployment continues, the long-term unemployed are likely to leave the labour market and retire or become members of a program for people with disabilities. At national level, high long-term unemployment jeopardizes overall employment policy goals, lowers access to decent work and lowers occupational and geographical mobility (Bejaković \& Mrnjavac 2018).

The causes of long-term unemployment are structural unemployment and cyclical unemployment. The recession leads to a massive increase in cyclical unemployment. Those who cannot find work become long-term unemployed. If they are out of work long enough, their skills become obsolete. Over time, this contributes to structural unemployment. They have less money to spend, which reduces consumer demand. This further slows economic growth, leading to more cyclical unemployment (Amadeo, 2021).

\section{Conclusions}

1. To increase GDP, it is necessary to increase women's participation in the labour force. Support measures for women should be provided both by the NEA and other state and local government institutions, as the number of unregistered unemployed women is high.

2. In order to prevent the unemployed from registering with the NEA only to receive unemployment benefits and do not plan to look for work, thus wasting NEA resources, it is necessary to improve the rules for granting downtime benefits to all employees who plan to work for their current employer when they are able to resume fullfledged economic activity.

3. Increased attention should be paid to the unemployed who have become or are at risk of becoming long-term unemployed, while maintaining and improving, as far as possible, the job skills of the unemployed in line with labour market requirements.

\section{Acknowledgements}

The research was supported by the National Research Program, the project "Economic, Political and Legal Framework for Preserving the Potential of the Latvian Economy and Promoting the Growth of Competitiveness after the Crisis Caused by the Pandemic (reCOVery-LV)" No VPPCOVID-2020/1-0010 (VP42) 


\section{References}

Amadeo, K. (2021, March). What Is Long-Term Unemployment? Retrieved March 6, 2021, from https://www. thebalance.com/long-term-unemployment-what-it-is-causes-and-effects-3305518.

Bejaković, P., \& Mrnjavac, Ž. (2019, February). The danger of long-term unemployment and measures for its reduction: the case of Croatia. Economic Research-Ekonomska Istraživanja. 2018, 31 (1) 1837-1850. DOI: 10.1080/1331677X.2018.1521295.

Central Statistical Bureau of Latvia. (2021). Unemployment rate in January 2021. Retrieved February 8, 2021, from https://www.csb.gov.lv/en/Statistics/Covid19/Unemployment-rate-in-January-2021.

COVID-19. (2021, February). Distribution of Covid-19 in Latvia. Retrieved February 9, 2021, from https:// covid19.gov.lv/covid-19/covid-19-statistika/covid-19-izplatiba-latvija.

European Commission Regulation. (2017). Regulation (EC) No 1466/97 - strengthening the surveillance of budgetary positions and the surveillance and coordination of economic policies.

https:/eur-lex.europa.eu/legal-content/LV/LSU/?uri=celex:31997R1466.

Eurostat Statistics Explained. (2021, January). November 2020 Euro area unemployment at 8.3\% EU at 7.5\%. Retrieved February 8, 2021, from https://ec.europa.eu/eurostat/statistics-explained/index. php?title=Unemployment_statistics

ILOSTAT. (2020, May). COVID-19 impact on the collection of labour market statistics. Retrieved February 9 , 2021, from https://ilostat.ilo.org/topics/covid-19/covid-19-impact-on-labour-market-statistics/.

International Labour Organization. (2021, February). Covid-19 and the world of work. Retrieved February 8 , 2021, from https:/www.ilo.org/global/topics/coronavirus/lang--en/index.htm.

International Labour Organization. (2021, January). ILO Monitor: COVID-19 and the world of work. Seventh edition. Updated estimates and analysis. Retrieved February 24, 2021, from https://www.ilo.org/wcmsp5/ groups/public/---dgreports/---dcomm/documents/briefingnote/wcms_767028.pdf.

International Labour Organization. (2018, March). The gender gap in employment: What's holding women back? Retrieved February 9, 2021, from https:/www.ilo.org/infostories/en-GB/Stories/Employment/ barriers-women\#intro.

LV portal. (2020, May). Downtime benefit denial is becoming less. Retrieved February 17, 2021, from https:// lvportals.lv/skaidrojumi/316109-dikstaves-pabalsta-atteikumu-klust-mazak-2020.

Ministry of Finance. (2020). Latvia's Stability Program 2020-2023. https://www.fm.gov.lv/sites/fm/files/ fminfo_30042020_sp1.pdf.

Ministry of Health. (2021). News about Covid-19. https://www.vm.gov.lv/lv/aktualitates-par-covid-19.

SKDS. (2020, November). About us. Retrieved February 9, 2021, from https:/www.skds.lv/about-us.

Public broadcasting of Latvia. (2021, February). Pavluts: Covid-19 restrictions are not working, the government will have to look for new solutions. Retrieved February 25, 2021, from https:/www.lsm.lv/raksts/zinas/ latvija/pavluts-covid-19-ierobezojumi-nedarbojas-valdibai-bus-jamekle-jauni-risinajumi.a394230/.

Republic of Latvia Cabinet Regulation. (2020). Republic of Latvia Cabinet Order No. 655. Regarding Declaration of the Emergency Situation. Latvia.

Republic of Latvia Cabinet Regulation. (2020). Republic of Latvia Cabinet Regulation No. 165 Regulations Regarding the Employers Affected by the Crisis Caused by COVID-19 which are Eligible for the Allowance for Idle Time and Division of the Payment for Late Tax Payments in Instalments or Deferral Thereof for up to Three Years. Latvia.

Republic of Latvia Cabinet Regulation. (2020). Republic of Latvia Cabinet Regulation No. 709 Rules on support for downtime for taxpayers to continue their activities in the context of the Covid-19 crisis. Latvia.

Republic of Latvia Cabinet Regulation. (2011). Republic of Latvia Cabinet Regulation No. 75 Regulations Regarding the Procedures for the Organising and Financing of Active Employment Measures and Preventative Measures for Unemployment Reduction and Principles for the Selection of Implementers of Measures. Latvia.

Republic of Latvia Law. (2002). Support for Unemployed Persons and Persons Seeking Employment Law. Latvia.

National Employment Agency. (2020). Name of the active employment or preventive measure. https://www. nva.gov.lv/lv/2020gads.

The Washington Post. (2021, May). Women have been hit hardest by job losses in the pandemic. And it may only get worse. Retrieved February 25, 2021, from https://www.washingtonpost.com/dc-md-va/2020/05/09/ women-unemployment-jobless-coronavirus/.

World Bank Group. (2021, January). Global Economic Prospects. Retrieved February 9, 2021, from https:// www.worldbank.org/en/publication/global-economic-prospects. 